\title{
Sintering, Properties and Applications of Silicon Nitride and Sialon Ceramics
}

\author{
Mamoru MITOMO and Yo TAJIMA* \\ National Institute for Research in Inorganic Materials, 1-1, Namiki, Tsukuba-shi, Ibaraki 305, Japan \\ *Research and Development Center, NGK Spark Plug Co., Ltd., 2808, Iwasaki, Komaki-shi, Aichi 485, Japan
}

\author{
窒化ケイ素・サイアロンセラミックスの焼結, 特性と応用 \\ 三友 護・多島 容* \\ 科学技術庁無機材質研究所, 305 つぐ市並木 1-1 \\ *日本特殊陶業(株)総合研究所, 485 小牧市大字岩崎 2808
}

\begin{abstract}
高性能窒化ケイ素及びサイアロンセラミックスの開発にはめざあしい進歩がみられるが，これには焼結挙動やプ ロセス・微構造と特性との関係についての研究成果に負うところが大きい. 本稿では, 焼結機構や燒結への影響 因子, 更に微構造と特性との相関についてこれまでの研究成果を概観する。これらの研究成果に基づき, 化学組 成や焼結条件を適正化することにより，二重粒径分布を持つ高勒性材料（in-situ composites），あるいは，粒界 ガラス相をほとんど含まない耐熱材料が製造できるようになってきている. エンジン部品や産業用部品としての いくつかの応用についても紹介する.
\end{abstract}

[Received April 5, 1991]

\begin{abstract}
There have been a great deal of progress in the development of high performance silicon nitride and sialon ceramics, largely owing to better understandings of sintering phenomena and processing-microstructureproperties relations. In this paper, sintering mechanisms and factors affecting sintering are reviewed for the systems with both soluble and insoluble additives, followed by discussions on the microstructure-properties relations. By choosing appropriate chemical compositions and sintering conditions, it has become possible to fabricate tough "in-situ composites" having bimodal grain size distributions or heat resistant ceramics with little grain boundary glass. Some examples of applications as heat engine components and industrial parts are also shown.
\end{abstract}

Key-words : Silicon nitride, Sialon, Sintering, Microstructure, Strength, Fracture toughness, Application

\section{Introduction}

$\mathbf{I}$ $\mathrm{T}$ was shown that silicon nitride ceramics have promising thermal and mechanical properties as high temperature materials as early as in 1955.1) The applications as high temperature engineering materials were suggested a little later. ${ }^{2)}$ The reaction bonding (RB) was an only method to fabricate the ceramics in those days. Strength of the reaction bonded materials, however, was too low for suggested applications because of large amounts of residual pores. High density materials were first fabricated by hotpressing (HP) with oxide additions, ${ }^{3)}$ but only simple shapes were possible by hot-pressing.

Research topics on the silicon nitride ceramics and components were focused on the application into gas turbines ${ }^{4), 5)}$ at the beginning of 1970 's. The fabrication of the high density and complex shape ceramics was made possible by the development of normal sintering ${ }^{6)}$ and gas pressure sintering. ${ }^{7), 8)}$ Successful applications of ceramic components into automobile engines have started recently. ${ }^{9)}$

During investigation on sintering of silicon nitride, some oxides were found to dissolve into $\beta-\mathrm{Si}_{3} \mathrm{~N}_{4}$ grains. ${ }^{10), 11)}$ The solid solution has been referred to as "sialon". The creep and corrosion resistance of high density sialon was found to be better than those of sintered silicon nitride because of the elimination or reduction of grain boundary glassy phase. ${ }^{12)}$

There have been many investigations on the improvement of mechanical, thermal and chemical properties of silicon nitride based ceramics. The most important properties for engineering ceramics are mechanical properties, i.e. strength and fracture toughness. There may be two ways in materials development. One is to optimize microstructure of ceramics during sintering, i.e. monolithic ceramics. Another way is to reinforce silicon nitride matrix with foreign particles, whiskers or fibers. The SiC whisker reinforced ceramics have been extensively studied. ${ }^{13), 14)}$ In this review paper, however, only monolithic ceramics are covered. Characteristic phenomena of sintering, design concepts for materials development and mechanical properties of sintered materials will be discussed. Some typical applications as engineering ceramics are also shown.

2. Sintering of silicon nitride based ceramics

2.1 Liquid phase sintering

Silicon nitride is a basically covalent material, ${ }^{15), 16)}$ so that bulk diffusion is too low to be densified. ${ }^{17)}$ Additions of oxides have been used to fabricate high density materials.3) The additives form a liquid phase by the reaction with $\mathrm{Si}_{3} \mathrm{~N}_{4}$ and 
surface $\mathrm{SiO}_{2}$ on $\mathrm{Si}_{3} \mathrm{~N}_{4}$ powder at high temperatures. The liquid promotes the diffusion of materials through grain boundaries. Most additives do not dissolve in $\mathrm{Si}_{3} \mathrm{~N}_{4}$ grains and remain at grain boundaries after sintering, whereas some additives dissolve into grains during sintering. Such difference in solid solubility gives large influence on mechanical and thermal properties of sintered materials.

(1) Sintering with insoluble additives

One of the most common additives is $\mathrm{MgO}$. It reacts with $\mathrm{Si}_{3} \mathrm{~N}_{4}$ and surface silica on $\mathrm{Si}_{3} \mathrm{~N}_{4}$ powder to form a liquid phase at $>1515^{\circ} \mathrm{C}$. The phase relation of the system $\mathrm{Si}_{3} \mathrm{~N}_{4}-\mathrm{SiO}_{2}-\mathrm{MgO}^{18)}$ is shown in Fig. 1. The actual chemical composition depends on the amounts of added $\mathrm{MgO}$ and surface silica, i.e. oxygen content in silicon nitride powder. It is usually close to the tie line between $\mathrm{Si}_{3} \mathrm{~N}_{4}$ and $\mathrm{Mg}_{2} \mathrm{SiO}_{4}$. It means that $\mathrm{Si}_{3} \mathrm{~N}_{4}$ grains and liquid phase in the system $\mathrm{Si}-\mathrm{Mg}-\mathrm{O}-\mathrm{N}$ are present at sintering temperature $\left(>1600^{\circ} \mathrm{C}\right)$. The liquid phase consolidates as glassy phase when the ceramics are cooled to room temperature. Thin glassy phase of $<1 \mathrm{~nm}$ has been observed by transmission electron microscopy (TEM). ${ }^{19)}$ Yttrium oxide $\left(\mathrm{Y}_{2} \mathrm{O}_{3}\right)$ or lanthanide oxides are also effective for liquid phase sintering. Sintering temperature is higher than that for the $\mathrm{MgO}$ addition because of higher melting temperature in the Si-M-O-N system. ${ }^{20), 21)}$ The phase rela-

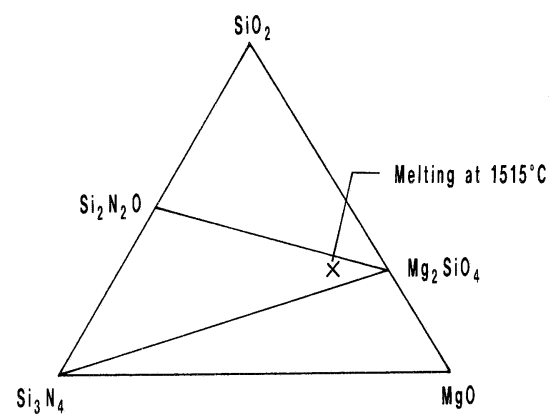

Fig. 1. Phase relations in the system $\mathrm{Si}_{3} \mathrm{~N}_{4}-\mathrm{SiO}_{2}-\mathrm{MgO}$. From $\mathrm{F}$. F. Lange, J. Am. Ceram. Soc., 62, 617 (1979).

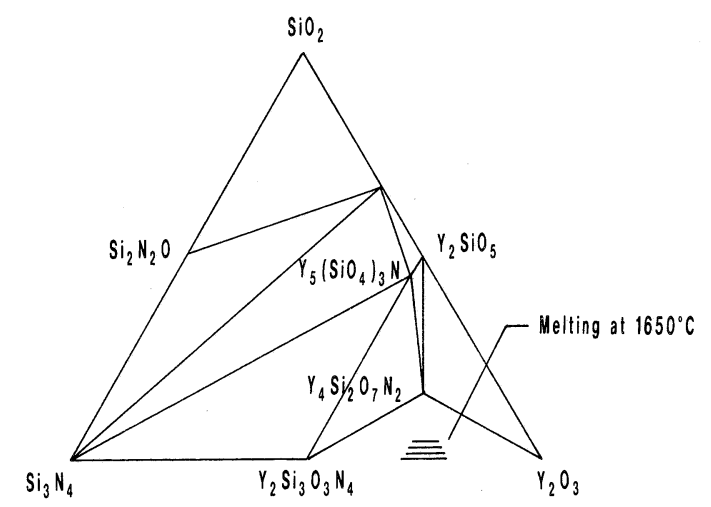

Fig. 2. Phase relations in the system $\mathrm{Si}_{3} \mathrm{~N}_{4}-\mathrm{SiO}_{2}-\mathrm{Y}_{2} \mathrm{O}_{3}$ at $1700^{\circ} \mathrm{C}$. From R. R. Wills et al., J. Mater. Sci., 11, 1305 (1976). tion in the $\mathrm{Si}_{3} \mathrm{~N}_{4}-\mathrm{SiO}_{2}-\mathrm{Y}_{2} \mathrm{O}_{3}$ system ${ }^{20)}$ is shown in Fig. 2. It is shown that the crystallization of oxynitride phases is possible in this system.

(2) Sintering with soluble additives

It was found that $\mathrm{Al}_{2} \mathrm{O}_{3}$ dissolves into $\beta$ - $\mathrm{Si}_{3} \mathrm{~N}_{4}$ structure at high temperatures. ${ }^{10), 11)} \mathrm{A}$ wide range of solid solubility was confirmed in the system $\mathrm{Si}_{3} \mathrm{~N}_{4}-\mathrm{SiO}_{2}$ $\mathrm{Al}_{2} \mathrm{O}_{3}$-AlN. ${ }^{11), 22)}$ The solid solution of $\beta$ - $\mathrm{Si}_{3} \mathrm{~N}_{4}$ is referred to as $\beta$-sialon. The general formula for the sialon is $\mathrm{Si}_{6-}{ }_{z} \mathrm{Al}_{z} \mathrm{O}_{z} \mathrm{~N}_{8-z}$, and a degree of solid solubility is expressed by a $z$-value. It represents that $\mathrm{Si}$ and $\mathrm{N}$ atoms in $\beta-\mathrm{Si}_{3} \mathrm{~N}_{4}$ structure are partly replaced by $\mathrm{Al}$ and $\mathrm{O}$ atoms, respectively. Some other metal oxides, i.e. $\mathrm{BeO}$ and $\mathrm{Ga}_{2} \mathrm{O}_{3}$, also dissolve into grains during sintering. When the starting powder mixture with appropriate composition, for example in the $\mathrm{Si}_{3}$ $\mathrm{N}_{4}-\mathrm{Al}_{2} \mathrm{O}_{3}$-AlN system, was heated, oxide reacts with nitrides to form liquid phase ${ }^{23)}$ as shown in Fig. 3. As sintering proceeds, then liquid then dissolves into grains resulting in the decrease of liquid phase at grain boundaries. This type of liquid is termed as "transient liquid".

The solid solutions of $\alpha-\mathrm{Si}_{3} \mathrm{~N}_{4}$, i.e. $\alpha$-sialon, are also formed in a narrow composition range in the system $\mathrm{Si}_{3} \mathrm{~N}_{4}$-AlN-oxides, ${ }^{24), 25)}$ where oxides are $\mathrm{CaO}$, $\mathrm{MgO}, \mathrm{Y}_{2} \mathrm{O}_{3}$ and lanthanide oxides. Mechanical properties of sintered $\alpha$-sialons are promising for engineering applications. ${ }^{26)}$

Phase relations containing $\mathrm{Si}_{3} \mathrm{~N}_{4}, \beta$ - and $\alpha$-sialon are shown as a prism for the $\mathrm{Y}_{2} \mathrm{O}_{3}$ addition in Fig. 4 . It must be noted that various ceramic materials developed so far are focused at near $\mathrm{Si}_{3} \mathrm{~N}_{4}$ corner in Fig. 4. The precise characterizations of phases, chemistry and microstructures are therefore necessary in interpreting mechanical and thermal properties.

\subsection{Mechanism of liquid phase sintering}

At the first stage of liquid phase sintering, solid particles move to give a more effective packing by a capillary force. This rearrangement process proceeds without the change of particle size, shape and crystalline phases. The contribution of the process to densification is proportional to the amount of liquid

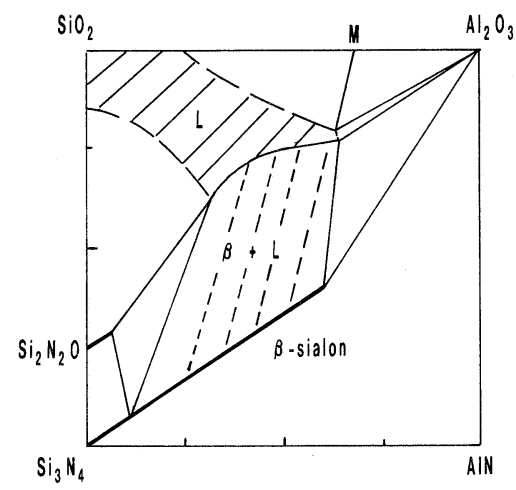

Fig. 3. Part of isothermal section of the system $\mathrm{Si}_{3} \mathrm{~N}_{4}-\mathrm{SiO}_{2}-$ AlN- $\mathrm{Al}_{2} \mathrm{O}_{3}$ at $1750^{\circ} \mathrm{C}$ showing solid-liquid equilibria. From I. K. Naik et al., J. Am. Ceram. Soc., 61, 332 (1978). 


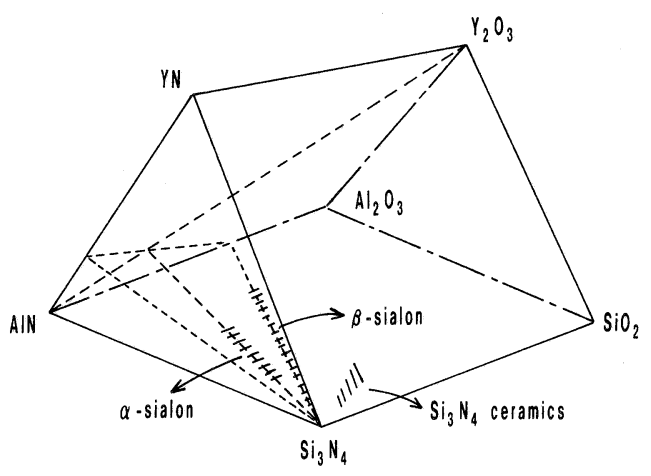

Fig. 4. The relationship between $\beta$-, $\alpha$-sialon and $\mathrm{Si}_{3} \mathrm{~N}_{4}$ ceramics in the system $\mathrm{Si}-\mathrm{Al}-\mathrm{Y}-\mathrm{O}-\mathrm{N}$.

phase. ${ }^{27)}$ The next step is solution-reprecipitation in which dissolution of small particles into liquid phase, diffusion through liquid phase and reprecipitation on large particles take place. ${ }^{8)}$ The phase transformation from $\alpha$ to $\beta$ occurs during the process when $\alpha$ phase powder is used. The rate determining step in solution-reprecipitation process is either diffusion through grain boundaries or interface reaction. Many kinetic equations have been proposed for the process depending upon rate determining step and grain shape. ${ }^{27), 28)}$ Kinetics of densification have been analyzed by plotting linear shrinkage as a function of sintering time. ${ }^{8), 29)-31)}$ Figure 5 shows the change of densification kinetics from the rearrangement process to the diffusion controlled solution-reprecipitation process with sintering time at various sintering temperatures. ${ }^{8)}$

During the densification, grain growth also takes place by materials transport through liquid phase. It is known that kinetics of grain growth depend also on the rate determining step. The rate of grain growth decreases with the increase of volume fraction of liquid phase in the diffusion controlled process, whereas it is independent in the reaction controlled process. ${ }^{32,33)}$ Since mechanical properties of ceramics depend largely on the microstructures, control of grain growth should be undertaken to at-

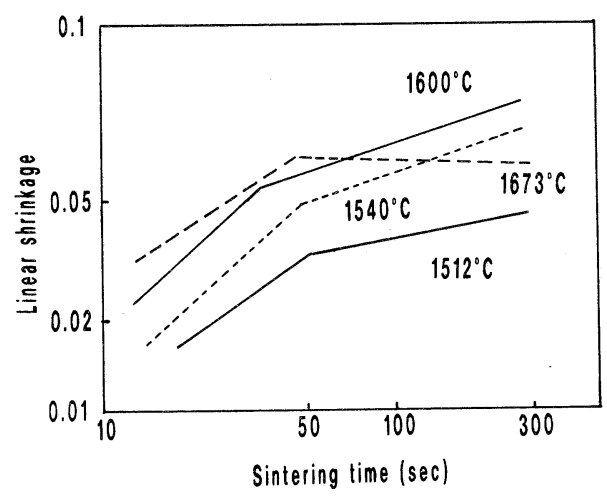

Fig. 5. Plots of linear shrinkage as a function of time which show the transition of sintering kinetics from rearrangement process to solution-reprecipitation process with time. ${ }^{8)}$ tain designed microstructure after sintering. The investigation on grain growth behavior during sintering of silicon nitride have started quite recently. ${ }^{34), 35 \text { ) }}$

The sintering of silicon nitride with soluble oxide is more complex. ${ }^{36), 37)}$ Chemical reactions between oxides and nitrides occur first to form a liquid. The dissolution of silicon nitride and reprecipitation as sialon grains take place together with densification. Many kinetic parameters affect the densification behavior because of transient nature of liquid phase.

2.3 Sintering method

\section{(1) Pressure sintering}

The powder mixture of $\mathrm{Si}_{3} \mathrm{~N}_{4}$ and additives is heated at high temperature under a pressure. The applied pressure enhances both rearrangement and diffusion. One method of pressure sintering is to apply uniaxial pressure, i.e. hot-pressing (HP). Only simple shape parts can be formed by HP. The strong ceramics were fabricated by hot-pressing. ${ }^{38)}$ Another method is to apply isostatic pressure, i.e. hot-isostatic-pressing (HIP). Complex shape parts can be formed by HIP, although they are more expensive. The amount of additives could be reduced by pressure application. ${ }^{39)}$

(2) Normal sintering

The powder mixtures are compacted to required shapes by various shaping methods. The most common and economical method is to sinter compacts under $0.1 \mathrm{MPa} \mathrm{N}_{2}$ at $1600^{\circ}-1800^{\circ} \mathrm{C}$, i.e. normal sintering (NS). Relatively large amounts of additives are necessary to fabricate high density materials, because the highest sintering temperature is restricted by thermal dissociation of $\mathrm{Si}_{3} \mathrm{~N}_{4}{ }^{8}$ ) The weight loss increases at higher temperatures which decreases density of materials.

(3) Gas pressure sintering

The dissociation of $\mathrm{Si}_{3} \mathrm{~N}_{4}$ is suppressed by heating under higher nitrogen pressure, ${ }^{7), 8)}$ i.e. gas pressure sintering (GPS). It is possible to sinter at higher temperatures by GPS than by other methods which accelerates materials diffusion through grain boundaries. The amounts of additives can be decreased as shown in Fig. 6. ${ }^{40)}$ The strength distribution also improved by gas pressure sintering as shown in Fig. 7.40) The strength of as-sintered materials fabricated

\begin{tabular}{|c|c|c|c|}
\hline \multirow{2}{*}{ Additive } & \multirow{2}{*}{ Process } & \multicolumn{2}{|c|}{ Relative density $(\%)$} \\
\hline & & $\begin{array}{r}80 \quad 90 \\
\end{array}$ & 100 \\
\hline \multirow{2}{*}{$10 \%$} & \multirow{2}{*}{$\begin{array}{l}\text { NS } \\
\text { GPS }\end{array}$} & $0.1 \mathrm{MPa} 1750^{\circ} \mathrm{C} 1 \mathrm{H}$ & \\
\hline & & \multicolumn{2}{|l|}{$8 \mathrm{MPa} 2000^{\circ} \mathrm{C} \quad 0.5 \mathrm{H}$} \\
\hline \multirow{2}{*}{$6 \%$} & NS & \multicolumn{2}{|l|}{$0.1 \mathrm{MPa} 1750^{\circ} \mathrm{C} 4 \mathrm{H}$} \\
\hline & GPS & \multicolumn{2}{|l|}{$8 \mathrm{MPa} 2000^{\circ} \mathrm{C}$ 1H } \\
\hline
\end{tabular}

Fig. 6. Relative density of ceramics attained by normal sintering (NS) and gas pressure sintering (GPS). ${ }^{40)}$ 


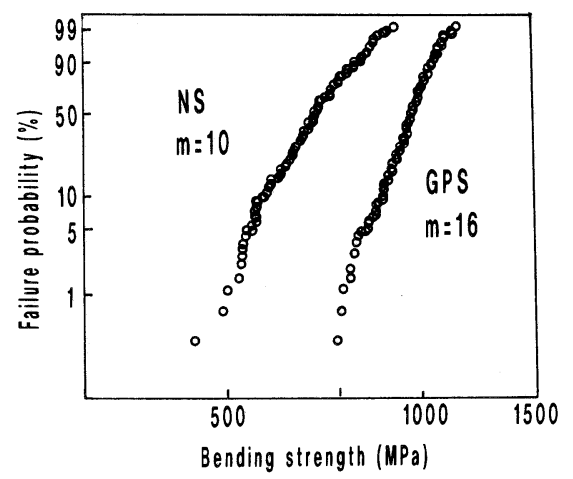

Fig. 7. Weibull plots of strength values of ceramics fabricated by normal sintering (NS) and gas pressure sintering (GPS). ${ }^{40)}$

by GPS was reported to be higher than that by NS. ${ }^{41)}$

(4) Dual sintering

Single sintering method is sometimes not good enough for the optimization of properties. Combinations of sintering methods have been attempted. Typical methods are RB-GPS ${ }^{42)}$ and NS-HIP.43) The former method can fabricate parts with better precision due to smaller shrinkage required for the full densification. The latter method is applied to increase density and strength.

\subsection{Factors affecting sintering}

It is well known that characteristics of starting powders largely influence sintering behavior and mechanical properties of sintered ceramics. ${ }^{44)}$ Various methods have been developed to produce fine and pure $\mathrm{Si}_{3} \mathrm{~N}_{4}$ powders. ${ }^{45)} \mathrm{A}$ large number of oxides have been evaluated as sintering additives. ${ }^{3), 46)}$ The additives form a liquid at high temperature. The amount and melting temperature of the liquid phase have the largest influence on sinterability of compacts, and these factors should be optimized depending on the required mechanical properties and the sintering method.

The thermal stability of $\mathrm{Si}_{3} \mathrm{~N}_{4}$ and liquid phase also has large influence on sinterability. ${ }^{47)}$ Thermal decomposition of $\mathrm{Si}_{3} \mathrm{~N}_{4}$ increases the amount of open pores which decreases the density of materials. ${ }^{48)}$ Thermal decomposition of oxynitrides results in the formation of $\mathrm{SiO}$ and $\mathrm{N}_{2}$ as gaseous products. ${ }^{49), 50)}$ The sintering stops at intermediate stage if the thermal decomposition occurs. The decomposition of liquid phase also decreases the density of materials by increasing open pores and diameter of closed pores (bloating). The evaporation of oxide additives is one of the possible reasons for low sinterability. ${ }^{51)}$ Thermal dissociation of $\mathrm{Si}_{3} \mathrm{~N}_{4}$ and oxynitrides was prevented by applying high nitrogen pressure. ${ }^{8,52), 53)}$ The application of high nitrogen pressure is also effective for reduction of equilibrium pore radius and increase of density. ${ }^{54), 55)}$

The amount of liquid phase decreases during sintering when transient liquid is used. The chemical reaction, like formation of liquid or solid solution, depends largely on temperature. On the other hand, densification behavior depends largely on sintering method. The formation of sialon and densification occurred concurrently during hot-pressing powder mixture of the $\mathrm{Si}_{3} \mathrm{~N}_{4}-\mathrm{Al}_{2} \mathrm{O}_{3}-\mathrm{AlN}$ system. The amount of residual grain boundary phase could be minimized by HP. ${ }^{36)}$ In the normal sintering, the sintering temperature shifts to higher temperature than that of sialon formation. The amount of transient liquid should be decreased at intermediate stage of densification. Extra liquid is necessary to attain full densification by NS. The amount of extra liquid could be minimized by suppressing thermal decomposition of liquid and sialon by sintering in the presence of $\mathrm{SiO}$ vapor. ${ }^{37)}$

It is generally acknowledged that any effort to optimize mechanical properties tend to make compacts difficult to sinter.

\section{Mechanical properties}

3.1 Design concept for materials development (1) Ceramic alloys

Ceramic materials sintered with insoluble additives, i.e. ceramic alloys, are usually composed of $\beta$ $\mathrm{Si}_{3} \mathrm{~N}_{4}$ grains and small amounts of grain boundary phases. A substantial fraction of the grain boundary phases is a glassy phase which is consolidated from a liquid during cooling. Partial crystallization occurs depending on the composition of the liquid phase. The amount of crystalline phase increases by heat treatment at low temperatures.

The fracture of ceramics is based on unstable crack propagation. The presence of a defect such as a pore, large grain, inclusion or surface flaw results in stress concentration. ${ }^{56)}$ The strength, $\sigma_{\mathrm{f}}$, is expressed as:

$$
\sigma_{\mathrm{f}}=\frac{K_{\mathrm{IC}}}{Y \sqrt{c}}
$$

where $K_{\mathrm{IC}}, Y$ and $c$ are fracture toughness, constant determined by a shape of the defect and defect size, respectively. The strength and strength distribution are related to the size and distribution of defects. It is the purpose of sintering to minimize the size and distribution of defects. Also, one should take a care to minimize the inhomogeneity during all the processing from powder preparation, shaping, sintering to surface finishing.

The fractured surface of a ceramic alloy is shown in Fig. 8(a). The figure shows that the fracture takes place predominantly at grain boundaries (intergranular fracture). The fracture toughness is related to the aspect ratio (length/diameter ratio) of grains when crack deflection is the main toughening mechanism. ${ }^{57), 58)}$. Anisotropic grains are required to fabricate high toughness ceramics. It is a contradicting requirement from that for the optimization of the defect size and distribution. But high fracture toughness is in many cases more important requirement for engineering ceramics to overcome the problem of 

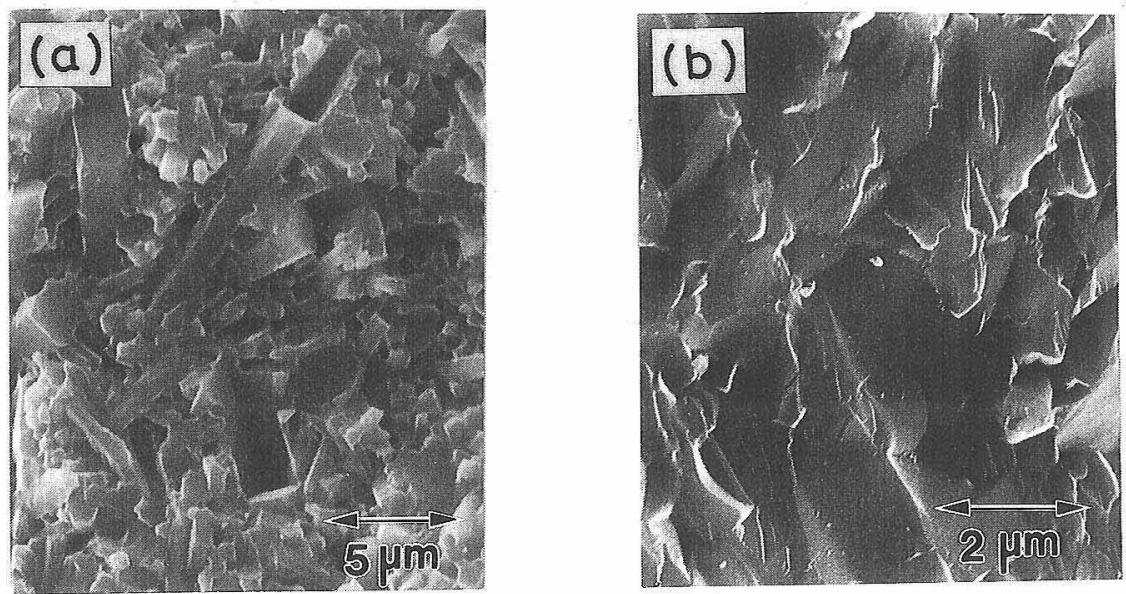

Fig. 8. Fractured surfaces of (a) ceramic alloy, and (b) single phase ceramics.

brittle fracture. It has been shown that high $\alpha$ content powder develops anisotropic grains during hot-pressing. ${ }^{.99), 60)}$ The fracture toughness increases with the increase of $\alpha$ content in the starting powder. It is assumed that $\alpha$ to $\beta$ phase transformation which occurs during the solution-reprecipitation process is responsible for the anisotropic grain growth, although true mechanism is not well understood.

The strength of ceramic alloys usually decreases at high temperature as shown in Fig. 9. The crack tends to grow under subcritical stress at high temperature due to the softening of grain boundary glassy phase. The slow crack growth increases critical defect size and decreases critical stress for fracture. The higher strength of hot-pressed materials with $\mathrm{Y}_{2} \mathrm{O}_{3}$ addition than that with $\mathrm{MgO}$ is related to the difference in viscosity of glassy phase. ${ }^{61), 62)}$

\section{(2) Single phase ceramics}

Single phase ceramics like $\beta$-sialon show transgranular fracture as shown in Fig. 8(b). Smooth fracture surface resulting from the low fracture toughness is similar to those observed for glasses and single crystals. On the other hand, the strength at high temperatures is about the same as that at room temperature as shown in Fig. 9. The relation between

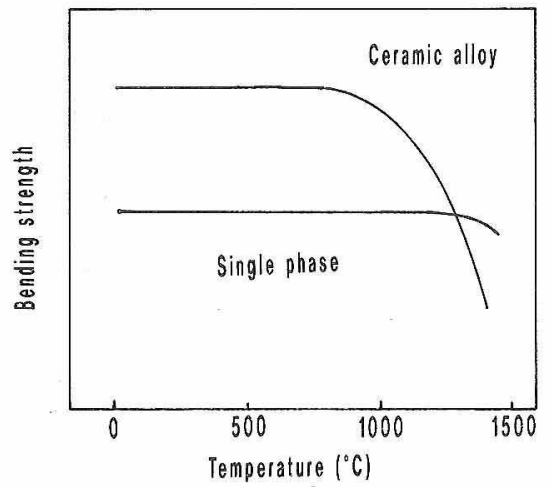

Fig. 9. The change of bending strength of single phase ceramics and ceramic alloys with temperature. strength and temperature in single phase ceramics is similar to that in sintered $\mathrm{SiC}$ with small amounts of additives. ${ }^{63)}$ The retention of strength up to high temperature is related to the same fracture behavior as that at low temperature, i.e. transgranular fracture.

(3) Design of microstructure

It is desirable to fabricate high strength and high fracture toughness ceramics. High temperature strength is particularly important for the heat engine applications. The degree of strength decrease at high temperature is represented by a ratio of strength at high temperature to that at room temperature. The ratio of strength at $1200^{\circ} \mathrm{C}$ and room temperature, $\sigma_{1200} / \sigma_{\mathrm{RT}}$, is a measure for heat resistance of ceramics. The general relation between the fracture toughness and heat resistance for typical ceramics is shown in Fig. 10. It is seen that it is difficult to fulfill the requirements for high fracture toughness and heat resistance with the same design concept.

There seems no way for toughening single phase ceramics without making composites. Extra oxide is added for the fabrication of high strength and high fracture toughnes $\beta$-sialon ceramics following a line of the concept of ceramic alloys. ${ }^{64)}$ Recent investiga-

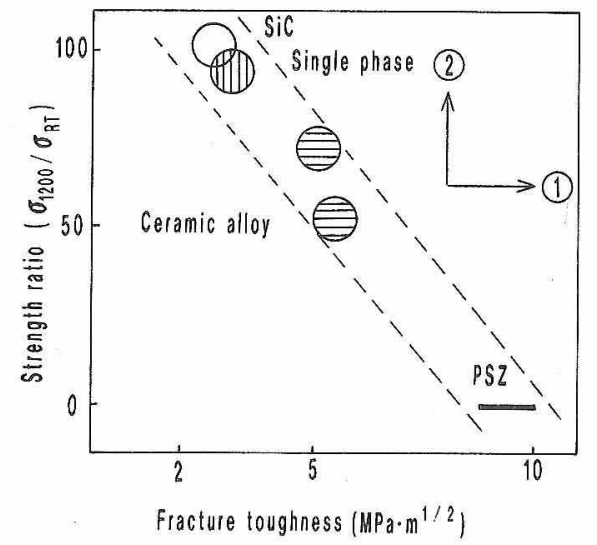

Fig. 10. The relation between strength ratio $\left(\sigma_{1200} / \sigma_{\mathrm{RT}}\right)$ with fracture toughness in normal sintered ceramics. 
tions for materials development in monolithic ceramics are therefore focused on toughening (1) in Fig. 10) or increase of heat resistance (2) in Fig. 10) of ceramic alloys.

\subsection{Toughening of $\mathrm{Si}_{3} \mathrm{~N}_{4}$ ceramics}

It is suspected that the phase transformation from $\alpha$ to $\beta$ phase that occurs during the liquid phase sintering enhances anisotropic grain growth. ${ }^{34), 65)}$ If the full densification is attained with partial phase transformation, the subsequent abnormal grain growth would be accelerated by the phase transformation because $\alpha$ is more easily dissolved into the liquid than $\beta$. Densification with the partial transformation is possible when the sintering conditions for hot-pressing ${ }^{30), 59), 66)}$ or normal sintering67) are optimized.

In the gas pressure sintering, phase transformation completes at intermediate stage of densification. $\left.{ }^{68)}, 69\right)$ The main densification process is accompanied by grain growth of $\beta$ grains, i.e. dissolution of small $\beta$ grains and reprecipitation on large $\beta$ grains. A microstructure of a gas pressure sintered material is shown in Fig. 11. A characteristic of the figure is a bimodal grain size distribution. It consists of a small number of large and anisotropic grains and a large number of small grains. As the microstructures of ceramics fabricated from $\beta$-type powders are reported to be uniform, ${ }^{35), 70)}$ it is most likely that a small number of nuclei responsible for the subsequent abnormal grain growth are formed during the phase transformation at the initial stage of densification. The high fracture toughness of this "in-situ composite" is related to aspect ratio, diameter and volume fraction of the abnormally grown grains. 34),69),71),72) Figure 12 shows the relation between the fracture toughness and the square root of the grain diameter of abnormally grown grains in the gas pressure sintered materials. ${ }^{73)}$ The results suggest that the large elongated grains contribute to toughening by not only the crack deflection mechanism but also the crack bridging mechanism. ${ }^{74)}$

The composite ceramics consisting of $\alpha$-sialon and $\beta$ - $\mathrm{Si}_{3} \mathrm{~N}_{4}$ grains were fabricated from powder mixtures of the $\mathrm{Si}_{3} \mathrm{~N}_{4}-\mathrm{AlN}-\mathrm{Y}_{2} \mathrm{O}_{3}$ system. ${ }^{75), 76)}$ High

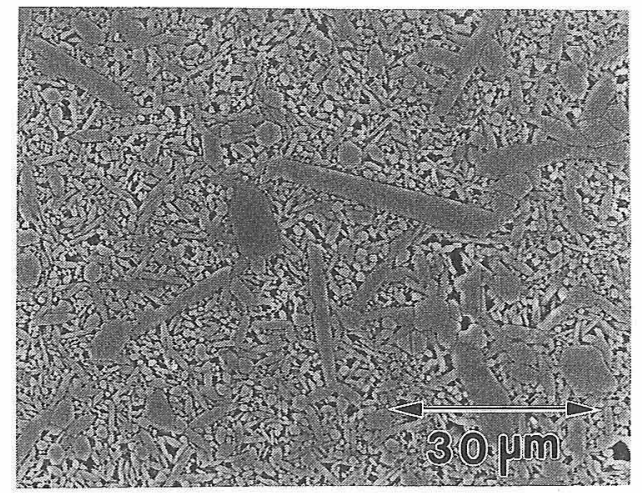

Fig. 11. Polished and etched surface of "in-situ composite". strength and high fracture toughness of the ceramics are related to the composite microstructures consisting of large and elongated $\beta-\mathrm{Si}_{3} \mathrm{~N}_{4}$ grains and small $\alpha$ sialon grains. Similar in-situ composites of $\alpha$ - and $\beta$ sialon grains were fabricated in the $\mathrm{Si}_{3} \mathrm{~N}_{4}-\mathrm{Al}_{2} \mathrm{O}_{3}-$ AlN- $\mathrm{Y}_{2} \mathrm{O}_{3}$ system.77)

The development of large and anisotropic grains during sintering inhibits densification. One of the most important problems in the sintering of oxide ceramics has been to prevent abnormal grain growth.78),79) The sintered oxide ceramics are usually designed to have a dense microstructure with fine and equiaxed grains. In the fabrication of engineering ceramics, on the other hand, the ceramics with uniform microstructures may not be the designed one. It has been shown that the in-situ composite could be developed during sintering of $\mathrm{Si}_{3} \mathrm{~N}_{4}$ based ceramics. It is important to keep microstructure fine and uniform until intermediate stage of densification and to develop a small number of large and anisotropic grains at final stage of densification. ${ }^{80}$ A large number of small grains keep sinterability of compact high so as to attain high density ceramics. A small number of nuclei should grow abnormally at final stage. A parameter for sinterability, i.e. densification rate/grain growth rate, as a function of relative density is plotted in Fig. 13. A homogeneous compact (A in the figure) densifies with grain growth at final

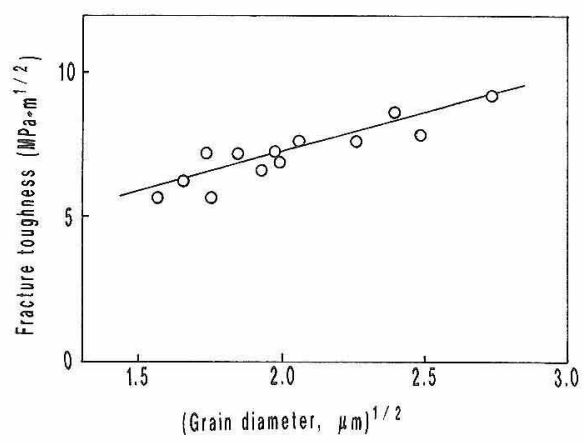

Fig. 12. Relation between fracture toughness and grain diameter of abnormally grown grains. From T. Kawashima et al. "Silicon Nitride Ceramics 2", Ed. by M. Mitomo and S. Sōmiya, Uchida Rokakuho (1990) p. 135.

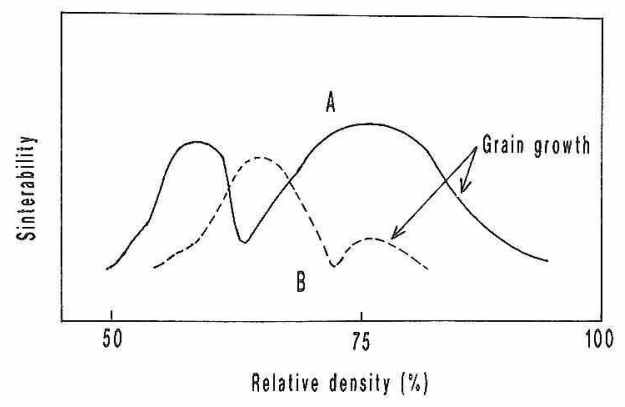

Fig. 13. The difference in sinterability between homogeneous (A) and heterogeneous compact (B). ${ }^{80)}$ 
stage. A heterogeneous compact (B in the figure) shows abnormal grain growth at intermediate stage and stops densification. It has been shown that the control of abnormal grain growth is important for the fabrication of the high density in-situ composites.

Another important factor is residual stress. It was shown that thermal and mechanical mismatches between grains and grain boundary phase produce residual stresses in ceramics. ${ }^{81,82)}$ It is proposed that the crack bridging is the most important toughening mechanism for the whisker reinforced ceramics. ${ }^{83)}$ The relation between microstructure and crack path may change with the change of residual stress. It means that the residual stress changes relative contributions of the toughening mechanisms. It is therefore important to control not only the microstructure but also the residual stress for toughening the in-situ composites.

\subsection{Improvement of heat resistance}

One way to improve high temperature strength of ceramics is to decrease the viscosity of grain boundary phases. The additions of stabilized $\mathrm{ZrO}_{2},{ }^{84)},{ }^{85)} \mathrm{Y}_{2}$ $\mathrm{O}_{3}{ }^{38,61), 86)}$ or $\left(\mathrm{Y}_{2} \mathrm{O}_{3}+\mathrm{La}_{2} \mathrm{O}_{3}\right)^{87), 88)}$ were successful for this purpose as shown in Fig. 14. Small amounts of $\mathrm{SiO}_{2}$ were also added for the cases of $\mathrm{ZrO}_{2}$ and $\mathrm{Y}_{2}$ $\mathrm{O}_{3}$ additions to increase the sinterability. The oxides of alkaline and alkaline earth metals decrease the viscosity of grain boundary glassy phase. High purity $\mathrm{Si}_{3} \mathrm{~N}_{4}$ powder was necessary for these works. ${ }^{89)}$ The contamination by metal oxides should be avoided during processing. These requirements make the compacts difficult to sinter. Hot-pressing or gas pressure sintering was employed to densify these compacts. It has been known that starting powders or compacts which are difficult to sinter may give high strength at high temperature.

Another way is to crystallize grain boundary glass by post-sintering heat treatments. ${ }^{90), 91)}$ The "crystallization" of highly refractory phase of $\mathrm{Si}_{3} \mathrm{~N}_{4} \cdot \mathrm{Y}_{2} \mathrm{O}_{3}$ in hot-pressed materials with $\mathrm{Y}_{2} \mathrm{O}_{3}$ addition increased high temperature strength. ${ }^{92)}$ The phase relations in the $\mathrm{Si}_{3} \mathrm{~N}_{4}-\mathrm{Al}_{2} \mathrm{O}_{3}-\mathrm{AlN}-\mathrm{Y}_{2} \mathrm{O}_{3}$ system ${ }^{93)}$ showed that $\beta$-sialon coexists with refractory oxide

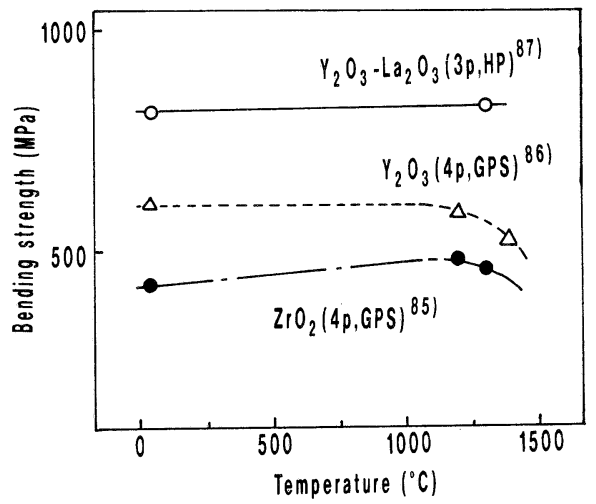

Fig. 14. The change of bending strength with temperature in materials fabricated with refractory oxide.
YAG $\left(\mathrm{Y}_{3} \mathrm{Al}_{5} \mathrm{O}_{12}\right)$. It has been reported that the complete devitrification of grain boundary phase is possible in this system.

It must be noted that microstructural design for toughening does not meet that for the improvement of heat resistance. It means that the optimization of microstructure should be done depending on the most important requirement for a particular application.

\section{Applications}

Silicon nitride based materials, as described in the previous section, have good mechanical and thermal properties. It should be stressed that one of the most important characteristics of these materials is that their properties are well balanced compared with other ceramic materials. For instance, toughened zirconia can exhibit much higher strength and toughness, but its higher temperature properties and thermal shock resistance are poor. Or, silicon carbide has excellent heat resistance but its toughness and thermal shock resistance are far behind.

Another important aspect is that various types of materials can be produced by changing starting powders, kinds and amounts of additives and manufacturing processes. One could choose either high toughness, high strength or heat resistant silicon nitride ceramics which have different chemistry and microstructures.

Silicon nitride ceramics are lighter and have better heat resistance and wear resistance than metals. These features make them the prime candidate materials for a gas turbine and other heat engines applications. Although the application to the gas turbine engine has not been commercialized yet, some engine components as well as some industrial parts made of these materials are now under commercial production stage.

\subsection{Engine components}

Table 1 summarizes engine components which are under commercial production. ${ }^{40), 94)-106)}$ Although purposes and requirements are somewhat different depending on the components, basic requirements are high strength, high thermal shock resistance and sufficient durability in order to assure that the components do not fail during the life of their services.

(1) Turbocharger rotor 40,94)-100) (Fig. 15)

The first production ceramic turbocharger rotor using gas pressure sintered silicon nitride (GPSSN) was introduced in October 1985, and, since then, the production volume has dramatically increased.

Prime objectives of the development of the ceramic rotor are improvement in acceleration response (or reduction in turbo-lag) and improvement in heat resistance, since the silicon nitride has lower specific gravity and better high temperature capabilities compared with conventional superalloys. The turbine rotor of a turbocharger operates under conditions of great stress, due to the high temperature and high 
Table 1. Applications of silicon nitride ceramics to heat engines.

\begin{tabular}{llll}
\hline Component & Purposes & Requirements for materials & References \\
$\begin{array}{l}\text { Turbocharger } \\
\text { rotor }\end{array}$ & $\begin{array}{l}\text { Response } \\
\text { Power }\end{array}$ & $\begin{array}{l}\text { Light weight } \\
\text { Heat resistance }\end{array}$ & $40,94-100$ \\
\hline $\begin{array}{l}\text { Quick start plug } \\
\text { Clean exhaust gas }\end{array}$ & $\begin{array}{l}\text { Heat resistance } \\
\text { Electrical insulation } \\
\text { Thermal shock resistance }\end{array}$ & 101 \\
\hline Swirl chamber & $\begin{array}{l}\text { Power } \\
\text { Clean exhaust gas }\end{array}$ & $\begin{array}{l}\text { Heat resistance } \\
\text { Thermal shock resistance }\end{array}$ & $102-104$ \\
\hline Rocker arm pad & Maintenance free & Wear resistance & 105,106 \\
\hline
\end{tabular}

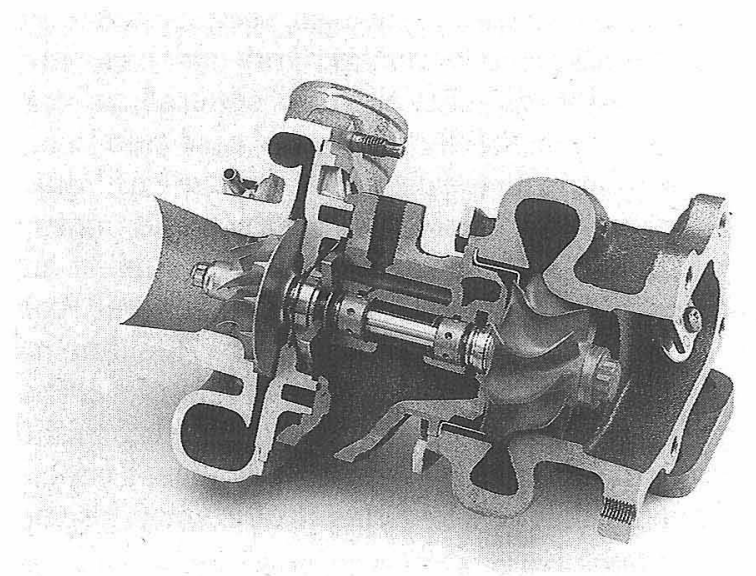

Fig. 15. Turbocharger with ceramic rotor.

speed of rotation. In addition, it must be reliably joined with a compressor rotor. Therefore, various development tasks including optimization of design, materials development, process engineering, joining technology and evaluation of reliability were needed to successfully develop the rotor.

In the process of developing the ceramic material, although the average failure speed of the hot spin test rose with the increasing material strength, the poor reliability of the material remained the problem to its practical use. The highly densified GPSSN showed high Weibull modulus in strength distribution (Fig. 7), and was expected to be the material eliminating this problem. Figure 16 shows the result of durability tests during over-speed condition of the GPSSN rotors. ${ }^{40)}$ The failure stress, which was calculated by FEM as combined stress from centrifugal and thermal stress, distributed in the range much higher than $100 \%$ rated stress. The fatigue behavior can be estimated by the equation in the figure, and the fatigue parameter, $n$, in the equation seems to be sufficiently high. From these results, it can be seen that the rotors made of GPSSN have high strength and high reliability.

(2) Other engine components

Ceramic glow plugs used in diesel engines consist of tungsten alloy heating element embedded in hotpressed silicon nitride. ${ }^{101)}$ Due to the excellent heat
Durability Testing of Rotor $\left(900^{\circ} \mathrm{C}\right)$

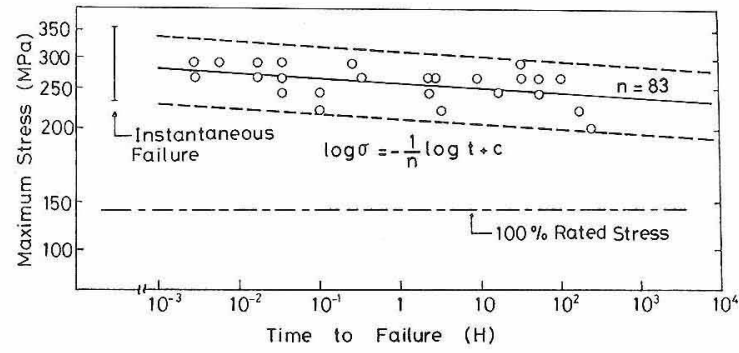

Fig. 16. Over-speed life test of ceramic rotor at $900^{\circ} \mathrm{C}$.

resistance of the silicon nitride, quicker heating, longer after-glow and longer service life compared with conventional metal glow plugs are made possible with the ceramic glow plugs. Commercial production of the ceramic glow plugs started in 1981 .

Ceramic swirl chambers are also used in diesel engines. ${ }^{102)-104)}$ In the recent turbocharged diesel engine, the combustion temperature is so high that the conventional metal chamber may be cracked due to the strength degradation at high temperature. ${ }^{103)}$ In this case, silicon nitride was used as the lower half of the swirl chamber. All ceramic swirl chamber was later developed in an attempt to reduce particulate emissions. ${ }^{104)}$

In the liquid propane fueled taxis, the combination of the fuel-burning characteristics and the frequent starts and stops resulted in inadequate lubrication of the rocker arm wear pads. Metal pads failed rapidly, whereas silicon nitride provided greatly improved wear life. ${ }^{105), 106)}$ Silicon nitride pads are either cast into or brazed to the metal rocker arm.

Although not commercially produced yet, use of the light weight silicon nitride ceramic valve offers greatly reduced inertia weight of the valve train. With the ceramic valve, higher output and improved fuel economy can be attained. A vehicle installed with the ceramic valves and piston pins (Fig. 17) were assembled and has traveled over 10,000 miles without component failure. ${ }^{107)}$

4.2 Industrial parts

(1) Bearings and balls ${ }^{108)-110)}$

Due to high heat resistance, hardness, elastic 


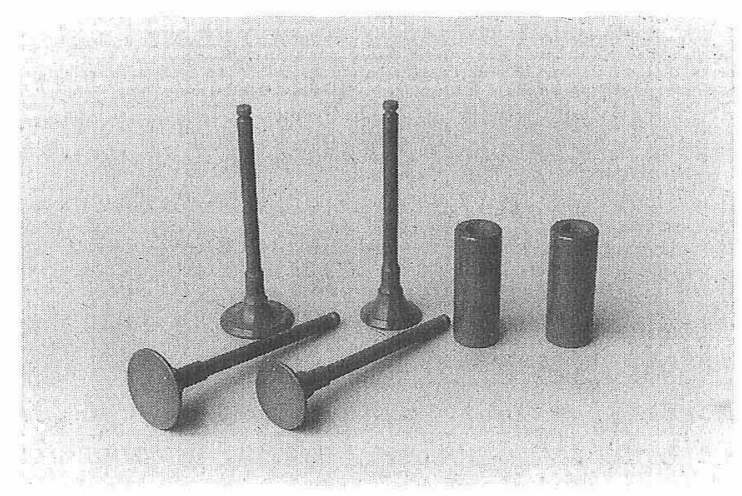

Fig. 17. Ceramic valves and piston pins.

modulus, wear resistance and corrosion resistance of ceramics, attempts to use ceramics as bearing materials started in the 1970 's. ${ }^{108), 109)}$ Among several candidate materials, silicon nitride exhibited failure mode due to fatigue similar to that of bearing steel; peeling off of surface layer, not catastrophic failure. For this reason among others, silicon nitride ceramics were chosen as the prime candidate materials, and silicon nitride ceramic balls for the bearings have been commercialized.110)

Silicon nitride ceramics are applied to bearings used under high temperature or corrosive atmosphere where metal bearings cannot be used and for ultra-high speed bearings where performance is greatly affected by the inertia of the rolling elements. Generally, all-ceramic bearings are used for the former application, and the hybrid bearings consisting of metal races and ceramic rolling elements (Fig. 18) are used for the latter application.

Materials for the bearings need to have very high reliability, as defects such as pores, inclusions and other inhomogeneities, even if they are small, could become sources of failure due to the rolling contact fatigue. It has been shown that the materials without such defects do have the longer fatigue life than steel. ${ }^{110)}$ Therefore, starting powders, powder processing conditions and densification conditions

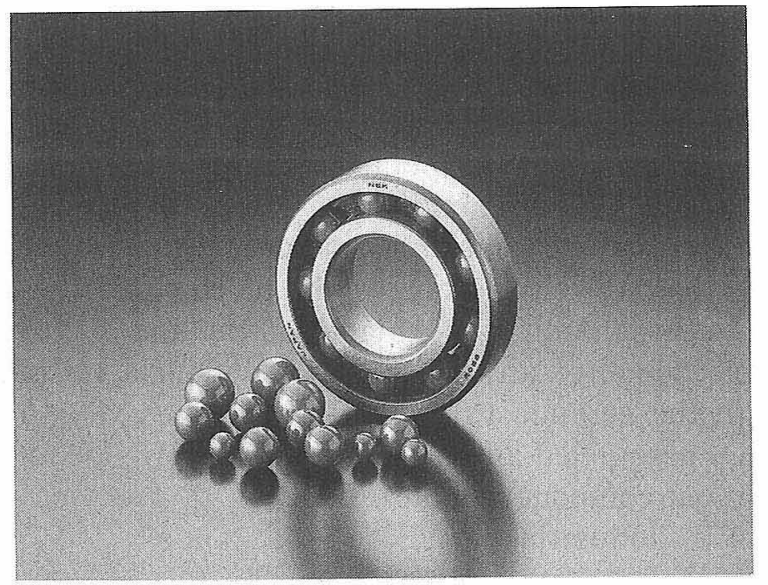

Fig. 18. Bearing with ceramic balls. have to be carefully optimized to eliminate those defects. Commercially available materials for the bearings are densified by either hot-pressing, hot isostatic pressing or gas pressure sintering.

(2) Cutting tools ${ }^{110)-114)}$

Silicon nitride is more heat resistant than toolsteel and tungsten carbide, and shows superior toughness and thermal shock resistance to $\mathrm{Al}_{2} \mathrm{O}_{3}$. These features made silicon nitride ceramics be widely applied as cutting tool materials. They have become popular because they allow vastly higher metal removal rates and subsequent productivity increase. ${ }^{111)}$

An essential limitation, however, seems to exist in machinable workpiece materials. Gray cast iron with lamellar graphite and nickel-based superalloys can be machined successfully, whereas cast iron with globular graphite (also called as "nodular" or "ductile" iron) and steel generate rapid wear progress. ${ }^{111)-113)}$ Reasons of good machinability of these workpiece materials are considered as follows. ${ }^{113)}$ Gray cast iron tends to be brittle, and so the chip/tool contact length is short. Therefore, the cutting temperature is relatively low resulting in the reduced wear. On the other hand, nickel-based superalloys have a relatively low chemical affinity for the tool materials.

The significance of temperature for the wear of the silicon nitride ceramic tools has been confirmed by results obtained in interrupted cutting. ${ }^{112)}$ In this case silicon nitride was employed successfully in steel cutting, because the toughness of the silicon nitride was adequate and interrupted cutting resulted in the lower cutting temperature. The same authors also reported the improvement of wear resistance in continuous cutting for tools with $\mathrm{TiC} / \mathrm{TiN}$ and $\mathrm{Al}_{2} \mathrm{O}_{3}$-coating.

When machining nickel-based superalloys with various types of sialon cutting tools, it has been reported that the wear resistance of $\beta$-sialon phase is strongly dependent on the $z$-values, increasing wear resistance as $z$ increases, and that $\alpha$-sialon phase is more dissolution wear resistant than the $\beta$-phase. ${ }^{113}$ ) Interactions of ceramic cutting tool materials including sialon with nickel-based alloys have been studied via diffusion tests. ${ }^{114)}$

\section{Future prospect}

Recent studies on processing-microstructurproperties relations have enabled us, to some extent, to design the materials with better properties. Recognition of the importance of heterogeneous microstructures is one of the important outcomes. It should be emphasized, however, that our current knowledge is by no means complete and that there are still a lot of "black boxes" and unanswered questions. For instance, our knowledge on the important characteristics of powders which affect sintering behavior and resultant materials properties, effects and controllability of sintering atmospheres, precise 
characterizations of grain boundary phases and many other issues is quite limited. Many scientific contributions are needed.

Technological innovation along with the scientific contributions should promote the development of better materials. At present, the attainable upper limits of properties seem unclear. Although it seems that it is difficult to achieve high strength, high toughness and high heat resistance at the same time, there would be a way to overcome this problem. Strengthening by nanoscale particles ${ }^{115)}$ is one of the opportunities that should be further exploited. Also, better understandings and control of the grain boundaries would be indispensable for the further improvement.

Regarding the applications, although commercial production of silicon nitride ceramics has shown sharp increase in its volume during the last decade, it is still in much smaller scale compared with the production of $\mathrm{Al}_{2} \mathrm{O}_{3}$ ceramics. One reason for this is undoubtedly higher costs of the silicon nitride ceramics. Therefore, reduction of the costs by improving manufacturing processes is one of the most important tasks for the ceramic engineers working in this field.

At the same time, further improvement of materials properties and innovation in design, evaluation, machining and joining among other technologies are essential to create new fields of applications because many mechanical engineers still believe that ceramic components are not as reliable as metal parts. So the key words for the successful future will be, as have been, "cost" and "reliability". Close interactions between users and manufacturers are quite important in this context.

\section{References}

1) J. F. Collins and R. W. Gerby, Metals, 7, 612-15 (1955).

2) N. L. Parr, Research, 13, 261-69 (1960).

3) G. G. Deeley, J. M. Herbert and N. C. Moore, Powder Metall., 8, 145-51 (1961).

4) D. J. Godfrey (Ed.), "Proceedings of the British Ceramic Society, Vol. 22”, British Ceramic Society (1973).

5) J. J. Burke, A. E. Gorum and R. N. Katz (Eds.), "Ceramics for High Performance Applications”, Brook Hill Pub. (1974).

6) G. R. Terwilliger, J. Am. Ceram. Soc., 57, 48-49 (1974).

7) M. Mitomo, M. Tsutsumi, E. Bannai and T. Tanaka, Am. Ceram. Soc. Bull., 55, 313 (1976).

8) M. Mitomo, J. Mater. Sci., 11, 1103-07 (1976).

9) M. Taguchi, Adv. Ceram. Mater., 2, 754-62 (1987).

10) Y. Oyama and O. Kamigaito, Jpn. J. Appl. Phys., 10, 1637 (1971).

11) K. H. Jack and W. J. Wilson, Nature (Phys. Sci.), 238, 2829 (1972).

12) K. H. Jack, J. Mater. Sci., 11, 1135-58 (1976).

13) K. Ueno and Y. Toibana, Yogyo-Kyokai-Shi (J. Ceram. Soc. Jpn.), 91, 491-97 (1983).

14) P. D. Shalek, J. J. Petrovic, G. F. Hurley and F. D. Gac, Am. Ceram. Soc. Bull., 65, 351-56 (1986).

15) L. Pauling, "Nature of Chemical Bond, 3rd ed.", Cornell Univ. Press (1960) pp. 97-102.

16) P. E. D. Morgan, "Nitrogen Ceramics", Ed. by F. L. Riley, Noordhoff Pub. (1977) pp. 23-40.
17) K. Kijima and S. Shirasaki, J. Chem. Phys., 65, 2668-71 (1976).

18) F. F. Lange, J. Am. Ceram. Soc., 62, 617-19 (1979).

19) D. R. Clarke and G. Thomas, J. Am. Ceram. Soc., 60, 49195 (1977).

20) R. R. Wills, S. Holmquist, J. M. Wimmer and J. A. Cunningham, J. Mater. Sci., 11, 1305-09 (1976).

21) M. Mitomo, F. Izumi, S. Horiuchi and Y. Matsui, J. Mater. Sci., 17, 2359-64 (1982).

22) L. J. Gauckler, H. L. Luckas and G. Petzow, J. Am. Ceram. Soc., 58, 346-47 (1975).

23) I. K. Naik, L. J. Gauckler and T. Y. Tien, J. Am. Ceram. Soc., 61, 332-35 (1978).

24) S. Hampshire, H. K. Park, D. P. Thompson and K. H. Jack, Nature, 274, 880-82 (1977).

25) Z. K. Huang, P. Greil and G. Petzow, J. Am. Ceram. Soc., 66, C96-97 (1983).

26) M. Mitomo, H. Tanaka, K. Muramatsu, N. Ii and Y. Fujii, J. Mater. Sci., 15, 2661-62 (1980).

27) W. D. Kingery, J. Appl. Phys., 30, 301-06 (1959).

28) R. M. German, "Liquid Phase Sintering”, Plenum Press (1985) pp. 127-55.

29) G. R. Terwilliger and F. F. Lange, J. Am. Ceram. Soc., 57, 25-29 (1974).

30) L. J. Bowen, R. J. Weston, T. G. Carruthers and R. J. Brook, J. Mater. Sci., 13, 341-50 (1975).

31) A. W. J. M. Rae, D. P. Thompson and K. H. Jack, "Ceramics for High Performance Applications II", Ed. by J. J. Burke, E. N. Lenoe and R. N. Katz, Brook Hill Pub. (1978) pp. 1369-74.

32) R. Warren and M. B. Waldron, Powder Metall., 15, 166201 (1972).

33) S. Sarian and H. W. Weart, J. Appl. Phys., 37, 1675-81 (1966).

34) G. Wötting, B. Kanka and G. Ziegler, "Technical and Engineering Ceramics", Ed. by S. Hampshire, Elsevier Appl. Sci. (1986) pp. 83-96.

35) M. Mitomo, M. Tsutsumi, H. Tanaka, S. Uenosono and F. Saito., J. Am. Ceram. Soc., 73, 2441-45 (1990)

36) M. H. Lewis, B. D. Powell, P. Drew, R. J. Lumby, B. North and A. J. Taylor, J. Mater. Sci., 12, 61-74 (1977).

37) M. Mitomo, N. Kuramoto and Y. Inomata, J. Mater. Sci., 14, 2309-16 (1979)

38) A. Tsuge, K. Nishida and H. Komatsu, J. Am. Ceram. Soc., 58, 323-26 (1975).

39) H. Larker, J. Adlerborn and H. Bohman, Proceedings of International Automotive Engineering Congress and Exposition, 770335 (1977).

40) Y. Hattori, Y. Tajima, K. Yabuta, Y. Matsuo, M. Kawamura and T. Watanabe, "Ceramic Materials and Components for Engines”, Ed. by W. Bunk and H. Hausner, German Ceram. Soc. (1986) pp. 165-72.

41) N. Hirosaki and A. Okada, Adv. Ceram. Mater., 3, 515-16 (1988).

42) J. A. Mangels and G. J. Tennenhouse, Am. Ceram. Soc., Bull., 59, 1216-22 (1980).

43) K. Honma, H. Okada and T. Tatsuno, Seramikkusu Ronbunshi (J. Ceram. Soc. Jpn.), 95, 323-29 (1987).

44) G. Wötting and G. Ziegler, Ceram. Int., 10, 18-22 (1984).

45) S. Sōmiya, M. Mitomo and M. Yoshimura (Eds.), "Silicon Nitride-1", Elsevier Appl. Sci. (1990).

46) K. Negita, J. Mater. Sci. Lett., 4, 755-58 (1985).

47) F. F. Lange, Int. Metals Rev., 1, 1-20 (1980).

48) G. R. Terwilliger and F. F. Lange, J. Mater. Sci., 10, 116974 (1975).

49) D. R. Messier and E. J. Deguire, J. Am. Ceram. Soc., 67, 602-05 (1984).

50) M. Mitomo, Y. Yajima and N. Kuramoto, J. Am. Ceram. Soc., 62, 316-17 (1979).

51) A. Giachello, P. C. Martinengo, G. Tommasini and P. Pop- 
per, J. Mater. Sci., 14, 2825-30 (1979)

52) C. Greskovich, S. Prochazka and J. H. Rosolowski, Final Technical Report SRD-76-151, AFML-TR-76-179 (1976).

53) A. Makishima, M. Mitomo, H. Tanaka, N. Ii and M. Tsutsumi, Yogyo-Kyokai-Shi (J. Ceram. Soc. Jpn.), 88, 701-02 (1980).

54) C. Greskovich, J. Am. Ceram. Soc., 64, 725-30 (1981).

55) S-J. L. Kang, P. Greil, M. Mitomo and J-H. Moon, J. Am. Ceram. Soc., 72, 1166-69 (1989).

56) A. G. Evans, J. Am. Ceram. Soc., 65, 127-37 (1982).

57) K. T. Faber and A. G. Evans, Acta Metall., 31, 565-76 (1983).

58) K. T. Faber and A. G. Evans, Acta Metall., 31, 577-84 (1983).

59) G. Himsolt, H. Knoch, H. Huebner and F. W. Kleinlein, $J$ Am. Ceram. Soc., 62, 29-32 (1979).

60) F. F. Lange, J. Am. Ceram. Soc., 62, 428-30 (1979).

61) G. E. Gazza. Am. Ceram. Soc. Bull., 54, 778-81 (1975).

62) R. A. L. Drew, S. Hampshire and K. H. Jack, "Special Ceramics 7", Ed. by D. Taylor and P. Popper, Brit. Ceram. Soc. (1981) pp. 119-32.

63) J. A. Coppola, M. Srinivasan, K. T. Faber and R. H. Smoak, "Proceedings of International Symposium on Factors in Densification and Sintering of Oxide and Non-oxide Ceramics", Ed. by S. Sōmiya and S. Saito, Gakujyutsu Bunken Fukyu-Kai (1979) pp. 400-07.

64) E. Butler, R. J. Lumby and A. Szweda, "Proceedings of International Symposium on Ceramic Components for Engine”, Ed. by S. Sōmiya, E. Kanai and K. Ando, KTK Sci. Pub. (1984) pp. 159-69.

65) H. Knoch, K. A. Schwetz and A. Lipp, "Progress in Nitrogen Ceramics", Ed. by F. L. Riley, Martinus Niihoff Pub. (1983) pp. 381-91.

66) H.Noch and G. Ziegler, Ber. Deut. Keram. Ges., 55, 242-45 (1978)

67) K. Matsuhiro and T. Takahashi, "Proceedings of MRS International Meeting on Advanced Materials", Ed. by M. Doyama, S. Sōmiya and R. P. H. Chang, Materials Research Society (1989) pp. 11-15.

68) M. Mitomo and K. Mizuno, Yogyo-Kyokai-Shi (J. Ceram. Soc. Jpn.), 94, 106-11 (1986).

69) M. Mitomo and K. Mizuno, "Ceramic Materials and Components for Engines", Ed. by W. Bunk and H. Hausner, German Ceram. Soc. (1986) pp. 263-70.

70) D-D. Lee, S-J. L. Kang, G. Petzow and D. N. Yoon, J. Am. Ceram. Soc., 73, 767-69 (1990).

71) E. Tani, S. Umebayashi, K. Kishi, K. Kobayashi and N. Nishijima, Am. Ceram. Soc. Bull., 65, 1311-15 (1986).

72) Y. Tajima, K. Urashima, M. Watanabe and Y. Matsuo, “Ceramic Powder Science II", Ed. by G. L. Messing, E. R. Fuller and H. Hausner, Am. Ceram. Soc., Inc. (1988) pp. 1034-41.

73) K. Kawashima, H. Okamoto, H. Yamamoto and A. Kitamura, "Silicon Nitride Ceramics 2", Ed. by M. Mitomo and S. Sōmiya, Uchida Rokakuho (1990) pp. 135-46 (in Japanese).

74) P. F. Becher, J. Am. Ceram. Soc., 74, 255-69 (1991).

75) K. Ishizawa, N. Ayuzawa, A. Shiranita, M. Takai, N. Uchida and M. Mitomo, Yogyo-Kyokai-Shi (J. Ceram. Soc. Jpn.), 94, 183-85 (1986).

76) Y. Ukyo and S. Wada, Seramikkusu Ronbunshi (J. Ceram. Soc. Jpn.), 97, 872-74 (1989).

77) C. Chatfield, T. Ekström and M. Mikus, J. Mater. Sci., 21, 2297-303 (1986).

78) R. J. Brook, J. Am. Ceram. Soc., 52, 56-57 (1969).

79) R. J. Brook, E. Gilbert, N. J. Shaw and U. Eisele, Powder Metall., 28, 105-07 (1985).

80) M. Mitomo, N. Yang, Y. Kishi and Y. Bando, J. Mater. Sci., 23, 3413-19 (1988)

81) J. Selsing, J. Am. Ceram. Soc., 44, 419 (1961).
82) D. J. Kim, P. Greil and G. Petzow, Adv. Ceram. Mater., 2 822-26 (1987).

83) P. F. Becher, C-H. Tsueh, P. Angelini and T. N. Tiegs, J. Am. Ceram. Soc., 71, 1050-61 (1988).

84） R. W. Rice and W. J. McDonough, J. Am. Ceram. Soc., 58, 264 (1975).

85） W. A. Sanders and D. M. Miekowski, Adv. Ceram. Mater. 1, 166-73 (1986).

86) J. D. Kiser, W. A. Sanders and D. N. Miekowski, Ceram. Eng. Sci., 7, 860-83 (1986).

87) K. Ueno and Y. Toibana, Yogyo-Kyokai-Shi (J. Ceram. Soc. Jpn.), 91, 409-14 (1983).

88) X. Youren, H. Liping, F. Xiren and Y. Dongsheng, Sci. Sinica, 28, 556-60 (1985).

89) D. W. Richerson. Am. Ceram. Soc. Bull., 52, 560-62 (1973).

90) A. Giachello, P. Martinengo, G. Tommasini and P. Popper, Am. Ceram. Soc. Bull., 59, 1212-15 (1980).

91) M. K. Cinibulk, G. Thomas and S. M. Johnson, J. Am. Cer am. Soc. 73, 1606-12 (1990).

92) A. Tsuge and K. Nishida, Am. Ceram. Soc. Bull., 57, 42426 (1976).

93) H. Hohnke and T. Y. Tien, "Progress in Nitrogen Ceramics”, Ed. by F. L. Riley, Martinus Niihoff Pub. (1983) pp. 101-09.

94) K. Katayama, T. Watanabe and K. Matoba, SAE Paper 861128 (1986).

95) K. Matoba, K. Katayama, M. Kawamura and T. Mizuno, SAE Paper 880702 (1988)

96) I. Matsuo and F. Nishiguchi, SAE Paper 880703 (1988).

97) M. Ito, N. Ishida and N. Kato, SAE Paper 880704 (1988).

98) B. Kitayama, Internal Combustion Engine, 26, 77-83 (1987).

99) C. Baker, R. Kobayashi and D. Baker, SAE Paper 890426 (1989).

100) T. Shimizu, K. Takama, H. Enokishima, K. Mikame, S. Tsuji and N. Kamiya, SAE Paper 900656 (1990).

101) O. Kamigaito, "Ceramics Engine”, Maruzen Ltd. (1987) p. 92 .

102) H. Matsuoka, H. Kawamura and S. Toeda, SAE Paper 840426 (1984).

103) S. Kamiya, M. Murachi, H. Kawamoto, S. Kato, S. Kawakami and Y. Suzuki, SAE Paper 850523 (1985).

104) Y. Tsukawaki, K. Shimono, M. Shigetu, SAE Paper 861408 (1986).

105) K. Tashiro, I. Tanaka, N. Miyamura and S. Nagano, J. Soc Automotive Eng. Jpn., 39, 1179-85 (1985).

106) M. Kano, J. Jpn. Soc. Tribologists, 34, 131-35 (1989).

$107)$ C. Suh, Y. Sato and T. Kojima, "Ceramic Materials and Components for Engines", Ed. by V. J. Tennery, The American Ceramic Society, Inc. (1989) pp. 1320-33.

108) H. R. Baumgartner, "Ceramics for High Performance Applications", Ed. by J. J. Burke, A. E. Gorum and R. N. Katz, Brook Hill Pub. Co. (1974) pp. 713-27.

109) H. R. Baumgartner, "Ceramics for High Performance Applications-II", Ed. by J. J. Burke, E. N. Lenoe and R. N. Katz, Brook Hill Pub. Co. (1978) pp. 423-43.

110) K. Yabuta, T. Kito, Y. Hattori and N. Kato, SAE Paper 890423 (1989)

111) L. R. Anderson, Cutting Tool Eng., [4], 65-70 (1990).

112) H. K. Tonshoff and S. Bartsch, Can. Metall. Quart., 28, 353-59 (1989).

113) J. Aucote and S. R. Foster, Mat. Sci. Tech., [2], 700-08 (1986).

114) H. Addhoum and D. Broussaud, Mat. Sci. Eng., A109, 379-87 (1989).

115) K. Izaki, K. Hakkai, K. Ando, T. Kawakami and K. Niihara, "Ultrastructure Processing of Advanced Ceramics", Ed. by J. D. Mackenzie and D. R. Ulrich, John Wiley \& Sons (1988) pp. 891-900. 


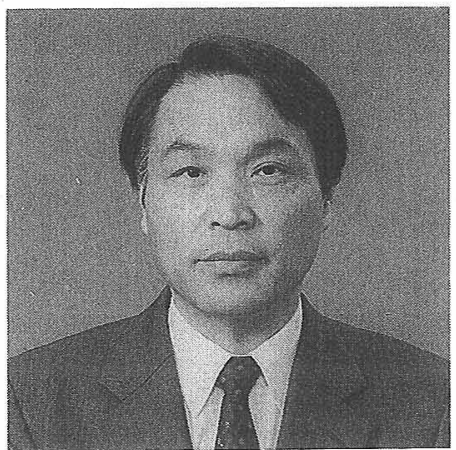

Mamoru MITOMO is a senior researcher at the National Institute for Research in Inorganic Materials. A graduate of Chiba University, he earned his M. S. from Chiba University in 1968 and Dr. Eng. from Tokyo Institute of Technology in 1980. He stayed in the University of Sheffield, England, in 1973-1974 as a guest scientist. He received 1985 Academic Award from the Ceramic Society of Japan.

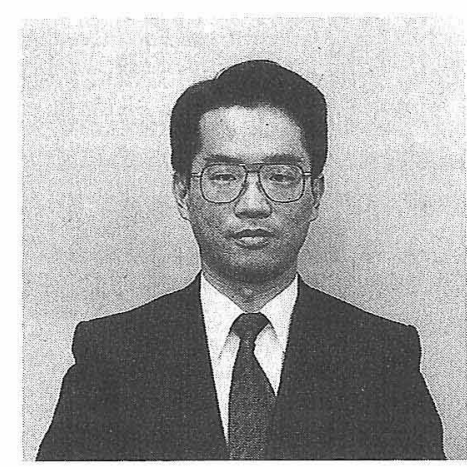

Yo TAJIMA is an assistant manager of engineering ceramics research in the Research and Development Center at NGK Spark Plug Co., Ltd., Aichi, Japan. He received a B. S. in inorganic materials engineering from Tokyo Institute of Technology in 1975 and a Ph. D. in ceramics from Massachusetts Institute of Technology in 1982. He has been with NGK Spark Plug Co., Ltd. since 1975. 